Mustafa Çalışkan, "Suriye'de PKK Faaliyetlerinin Tarihî Arka Planı ve PYD Terör Örgütünün Siyasallaşma Çabaları," Üsküdar Üniversitesi Sosyal Bilimler Dergisi, sayı: 10, (Mayıs 2020): 63-91,

\title{
Suriye'de PKK Faaliyetlerinin Tarihî Arka Planı ve PYD Terör örgütünün Siyasallaşma Çabaları
}

\author{
Historical Background of PKK Activities in Syria and \\ Politicalization of the PYD Terrorist Organization
}

\section{Mustafa ÇALIŞKAN ${ }^{*}$}

\section{$\ddot{0} \mathbf{z}$}

Ortadoğu'da 2010 yllında patlak veren "Arap Baharı" süreciyle başlayan toplumsal olayların en uzun soluklusu Suriye'de yaşanmaktadır. Suriye'de 2011 yılında başlayan iç savaş süreci günümüzde de devam etmekte olup, bu savaş süreci siyasallaşma amacı taşıyan terör gruplarının devletleşme amaciyla harekete geçmelerinde etkili olmuştur. Irakve Suriye idari sınılarında idari teşkilatlanma ideolojisiyle hareketeden DEAŞ terör örgütü, Dünya'nin dört bir tarafından gelen "Yabancı Terörist Savaşşılar" in da desteğiyle faaliyet gösterdiği alanı genişletmiştir. Bu aşamada DEAŞ terör örgütüne karşı harekete geçen PKK'nın Suriye parça yapılanması YPG, ABD ve Rusya desteğiyle silahlanarak, DEAŞ'tan arındırilan bölgelerde hâkimiyet kurma amacina yönelmiş olup, durumu firsat bilerek siyasallaşma aşamasına geçme çabasına girmiştir. Bu çalışmanın amact; Türkiye sinirinda terör devleti kurmaya çalışan PKK/PYD terör örgütünün Suriye'deki geçmişini inceleyerek günümüzde PKK ile illiyet bağın ve Suriye idari sınırları içerisinde yaşanan çatışmaların esasen devlet kurma ve siyasallaşma çabasında olan ikifarkh terör örgütünün mücadelesi olduğunu ortaya koyabilmektir.

Anahtar Kelimeler: Suriye, Terör, Terörizm, PKK, PYD.

\footnotetext{
Özgün Araştırma Makalesi (Original Research Article)

Geliş Tarihi: 18.02.2020

Kabul Tarihi: 15.04.2020

(*) Dr., İçişleri Bakanlığı, Emniyet Genel Müdürlüğü, İstanbul İl Emniyet Müdürü, mustafacaliskanakademik@gmail.com
}

ORCID ID: https://orcid.org/0000-0003-0342-571X 


\section{Mustafa ÇALIŞKAN}

\section{Abstract}

Among the social events sparked by "the Arab Spring" process that broke out in the Middle East in 2010, the longest-lasting is experienced in Syria. The civil war in Syria is still ongoing since 2011 and it paved the way for terrorist groups for mobilization with the aim of politicization to act for the purpose of a state formation. The DAESH terrorist organization, acting with the ideology of an administrative organization within Iraqi and Syrian administrative borders, has expanded its field of activity with the support of the "Foreign Terrorist Fighters" from all over the world. At this stage, YPG, the Syrian offshoot of the PKK, armed by the support of the USA and Russia, took action against the DAESH terrorist organization, and aimed to dominate the regions freed from the DAESH and attempted to move to the politicization phase by taking advantage of the situation. This purpose of this study is to present the causal link between the PKK and the PKK/PYD terrorist organizations that aim to establish

Üsküdar

University Journal of Social Sciences, 2020; issue: 10 , 63-91 a terrorist state along the borders of Turkey through an analysis PKK/PYD's past in Syria and to reveal that the conflicts occurring within the administrative borders of Syria are essentially a strife of two different terrorist organisations which are in pursuit of state formation and politicization.

Keywords: Syria, Terror, Terrorism, PKK, PYD.

\section{Giriş}

Amerika'da 11 Eylül 2001 saldırısı ve Londra'da yaşanan 2005 metro saldırıları sonrasında, Batı ülkelerinde yerel kaynaklı teröristlerin radikal ideolojileri benimsedikleri keşfedilmiş ve "Homegrown Terrorism"1 kavramına yönelik araştırmalar artmaya başlamıştır. Bu tür radikal ideolojileri benimseyenlerin, ideolojileri doğrultusunda savaşacağı bir

1 "Homegrown teröristler kavramına 21. yüzyılda küreselleşme” ile eş zamanlı rastlanmıştır. "Homegrown” Türkçeye "yerel”, "ev yapımı” "bahçede yetişen” gibi çevrilse de, bu kavram kastedilen anlamı karşılamıyor. Homegrown Batılı ülkelerde doğup büyüyen, orada eylem yapan veya sonra da savaşmak için başka bir ülkeye giden kimseleri tanımlamak için kullanılmaktadır (Hilmi Demir, "Yabancı Savaşçılar ve Homegrown Teröristler”, Türkiye Ekonomi Politikaları Araştırma Vakfi, Değerlendirme Notu, Mart 2015, https://www.tepav.org.tr/upload/files/1425653423-0.Yabanci_Savascilar_ve_ Homegrown_Teroristler.pdf 


\section{Suriye'de PKK Faaliyetlerinin Tarihî Arka Planı ve PYD Terör Örgütünün Siyasallaşma Çabaları}

coğrafya arayışı ise Suriye iç savaşıyla eş zamanlı olarak nihayete ermiştir. $\mathrm{Bu}$ süreçte, dünyada birçok devlet, kendi idari sınırlarında yaşayan ve resmi olarak vatandaşları olan yabancı savaşçıları sınırlarından çıkartma gayretinde olmuşlardır. Diğer taraftan, ihraç edilen savaşçıların da yer aldığı DEAŞ terörüne karşı verilen mücadelede, PYD’ye taraf olma hissiyatı bölgedeki egemen güçler açısından daha kabul edilebilir bir seçenek olarak görülmüştür. Oluşan bu siyasi tablo, PYD’nin siyasallaşmasına kapı aralamıştır.

Dışişleri Bakanlığı'nın 2018 yılı kayıtlarına göre Suriye topraklarındaki hapishanelerde bulunanlar hariç olmak üzere sınırlarımızı kullanmaya çalışan 61.000 kişiye ülkeye giriş yasağı konulmuş, 6.100 kişi sınırdışı edilmiş ve 3.588 kişi tutuklanmıştır. ${ }^{2}$ Buna ek olarak, Suriye’ye 32,809 erkek, 4,761 kadın ve 4,640 çocuk olmak üzere 80 ülkeden toplam 41,490 kişi farklı örgütlere katılarak savaşmak için Suriye'ye geçiş yapmıştır. ${ }^{3} \mathrm{Bu}$ durum terör örgütlerinin kuruluş ve yönetiminde geçmişten edinilen tecrübeler, terör örgütlerin de sürekli bir değişim ve gelişim sürecinde olduklarının önemli bir göstergesidir.

Çalışmada, Suriye idari sınırlarında PKK’nın parça yapılanması PYD’nin, DEAŞ’e karşı savaştı̆̆ı söylemi doğrultusunda siyasallaştırılma çabaları ve dünya çapında propaganda faaliyetleriyle, PKK'dan ayrı bir yapı olarak faaliyet gösterdiğine yönelik algı oluşturma aşamaları incelenmiştir. Günümüzde, Suriye iç savaşı örneğinde olduğu üzere, terör oluşumlarının özerk yönetim isteği doğrultusunda siyasi bir aktör haline gelme çabaları,

${ }^{2}$ Dışişleri Bakanlığı, “Türkiye'nin Yabancı Terörist Savaşçılarla Mücadelesi,” http:// www.mfa.gov.tr/turkiye_nin-yabanci-terorist-savascilarla-mucadelesi.tr.mfa

${ }^{3}$ Örgüte katılanların \%13'üne takabül eden 4,761 kişi kadın, \%12'lik orana denk gelen 4,640 kişi ise 18 yaş altı çocuklardan oluşmaktadır (ICSR Team, "From Daesh to 'Diaspora': Tracing the Women and Minors of Islamic State," 23 Temmuz 2018, erişim 28 Kasim 2019, https://icsr.info/2018/07/23/from-daesh-to-diaspora-tracing-thewomen-and-minors-of-islamic-state/ 


\section{Mustafa ÇALIŞKAN}

örgütlerin tarihi arka planlarının ve ideolojik motivasyon kaynaklarının bilinmesiyle mümkün olabilir. Bu bağlamda, çalışmaya konu olan terör oluşumlarının ana ekseni; Irak, Suriye, Türkiye ve İran idari sınırlarından kazanım elde edilmesi çerçevesinde şekillenmiştir. Konu "Dört Parçalı Kürdistan”ın birleştirilmesi ideolojisi doğrultusunda ele alınmış ve Suriye'nin terör oluşumlarına desteği kapsamında değerlendirilmiştir. Çalışmada, Suriye sınırlarında terör oluşumlarının geçmişten günümüze kadar olan süreçteki faaliyetleri ele alınmış ve PYD-PKK arasındaki illiyet bağının daha iyi gözlemlenebilmesi amaçlanmıştır.

Üsküdar University Journal of Social Sciences, 2020; issue: 10 , 63-91

\section{Kürtçülük Faaliyetlerinin Örgütlenme Sürecinde KDP ve PKK Faktörleri}

Özellikle Osmanlı Devletinin son yüzyılında baş gösteren Kürtçülük sorunu, 1916 tarihli Sykes-Picot Antlaşması́yla çok farklı bir evreye girmiştir. I. Dünya Savaşı sonrasında Kürtlerin yaşadığı coğrafyanın dört parçaya bölünmesi, her parçanın farklı bir devletin idari sınırlarında yer almasına neden olmuştur. Bu durum Kürtçülük faaliyetlerinin tek elden yönetilmesini engellerken bölgede sömürü düzeni kurmak ve devletlerarası güç dengesi oluşturmak isteyen devletler açısından önemli bir kazanım olarak görülmüştür. Bu nedenledir ki, Sykes-Picot sonrası kurulan Ortadoğu düzeninde organize edilen Kürtçülük faaliyetleri, bölgedeki hegemon devletlerin sömürgecilik faaliyetleri açısından eşsiz bir firsat sunmuştur.

Türkiye, Irak, İran ve Suriye devletleri bir taraftan kendi siyasi sınırlarında ortaya çıkan Kürtçü örgütlenmelerle yıllarca mücadele etmek zorunda kalırken; diğer taraftan bu örgütlenmeler farklı devletler tarafından desteklenerek, belirtilen devletlere karşı bir tehdit unsuru olarak kullanılmaktadır. Bu durum örgütsel faaliyetlerin canlılı̆̆ını korumasında da etkili olmaktadır. Kürtlerin yaşadığı coğrafyanın farklı 
idari sınırlar kapsamında dört parçaya bölünmesi, Kürtçü örgütlenmelerin bu parçaları bütün haline getirip "Büyük Kürdistan” hayalini hayata geçirme amacıyla harekete geçmelerinin ana motivasyon kaynağıdır. Bu bağlamda bahsedilen bir devlette kurulan bir örgütlenme diğer devletler açısından, o devleti zayıflatma amacıyla bir kazanım olarak görülmüş ve destek verilen örgütlerin zamanla 4 devlette şemsiye organizasyonu olarak örgütlenme kabiliyetini elde edebilmelerine imkân tanımıştır. SykesPicot Antlaşması sonrasında ortaya çıkan coğrafi bölünme neticesinde Kürtçü örgütlenmeler; Türkiye'nin güneydoğusunu "Kuzey Kürdistan” Irak’ın Kuzeyini “Güney Kürdistan” Suriye'nin Kuzeyini "Batı Kürdistan” ve İran’ın Kuzeydoğusunu “Doğu Kürdistan” olarak adlandırmışlardır. $\mathrm{Bu}$ yeni tanımlar arasında ise Hakkari "Merkezi Kürdistan” olarak belirtilmektedir. ${ }^{4}$

Kürtçü örgütlenmelerde "demokratlık” kavramının ideolojik temelini güçlendiren, şemsiye organizasyon olarak adlandırılan KDP olmuştur. KDP-İ 1945'te İran'da Kadı Muhammed yönetiminde kurulmuş ve genel sekreterlikbünyesinde örgütlenmiştir. Bu örgütlenmenin 1946'da İran'daki otorite boşluğunu kullanarak Mahabad Cumhuriyeti'nin kurulduğunu ilan etmesi ve sınır boylarında örgütlenmesi diğer devletler açısından da örnek teşkil etmiştir. 1946 yılından sonra KDP Kürtçülük faaliyetlerin ana eksenini oluşturmuş ve örgütlenmenin zamanla dört devlet bünyesinde; KDP-İ (1945), KDP-I (1946), KDP-S (1957) ve KDP-T (1965) adları altında faaliyet göstermesinin itici gücünü oluşturmuştur. KDP’nin dört devleti kapsayan şemsiye organizasyonu olabilme becerisi sistemi ilerleyen yıllarda kurulan PKK tarafından da örnek alınmıştır. PKK’nın KDP örneğinde olduğu üzere parti genel sekreterliği bünyesinde ve

${ }^{4}$ Françis Richard Maunsel, "Central Kurdistan”, The Geographical Journal, (London: 1901), 121-144; aktaran Levent Ayabakan, “Kürt-İngiliz İlişkileri 1918-1923," (Yayımlanmamış Doktora Tezi, Sakarya Üniversitesi, 2016), 7. 


\section{Mustafa ÇALIŞKAN}

dört farklı devlette örgütlenmesi ${ }^{5}$ bunun en önemli ispatlarından birisini oluşturmaktadır. ${ }^{6}$

1940 ve 1970 yılları arasında KDP’nin şemsiye organizasyonu olması örneğinde olduğu gibi PKK da benzer bir şemsiye organizasyonuna yönelmiştir. 2004'te, Kürdistan'ın Özgür Yaşam Partisi (PJAK) olarak adlandırılan örgütün kuruluşu bunun önemli bir işaretiydi. İran İslam Cumhuriyeti’ne karşı silahlı mücadele adı altında örgütsel faaliyetlere girişen PJAK, PKK ile örgütsel, ideolojik ve retorik benzerliklere sahipti. Gerek Türkiye gerekse İran'daki hükümet yetkililerinin girişimleri sonucundaPJAK'ınPKKileayniideolojiylefaaliyetgösterdiğikamuoyunda kabul edilmeye başlamıştı.' İran ve Türkiye'nin ortak girişimiyle PJAK,

Üsküdar University Journal of Social Sciences, 2020; issue: 10, 63-91 terör örgütleri listesine girerken, Suriye'nin teröre verdiği açık desteğin tarihi geri planı, PYD'nin parça örgütlenmesinin dünya kamuoyunda PJAK örneğinde olduğu gibi değerlendirilmemesinde etkili olmuştur. Bu kapsamda PKK-PYD’nin Suriye coğrafyasındaki geçmişini incelemek çalışmaya farklı bir bakış açııı kazandıracaktır.

\section{Suriye Baas Rejimi ve PKK}

Suriye'de bölgesel yönetim iddialarının ortaya çıkması ve terör devleti projelerinin hayata geçmesine neden olan öncü faktörler incelenmeden bugünkü durum anlaşılamayacağından, Hafız Esad döneminde terör örgütlerine verilen desteğin tekrar hatırlanması gerekmektedir.

\footnotetext{
${ }^{5}$ Ayabakan, "Kürt-İngiliz İlişkileri 1918-1923,” 292.

${ }^{6}$ İçişleri Bakanlığı, PKK/KCK Terör Örgütünün Suriye Kolu: PYD-YPG, (2017), 20, erişim 7 Aralık 2019, https://www.icisleri.gov.tr/kurumlar/icisleri.gov.tr/IcSite/ strateji/deneme/YAYINLAR/\%C4\%B0\%C3\%87ER\%C4\%B0K/pyd_arapca.pdf

${ }^{7}$ Andrew Self ve James Michael Ferris, "Dead Men Tell No Lies: Using Killed-in-Action (KIA) Data to Expose the PKK's Regional Shell Game," Defence Against Terrorism Review (DATR) 8, (2016): 9-35.9-10.
} 


\section{Suriye'de PKK Faaliyetlerinin Tarihî Arka Planı ve PYD Terör Örgütünün Siyasallaşma Çabaları}

1980 askeri darbesinin hemen öncesinde PKK terör örgütü, Türkiye idari sınırlarındaki hücrelerinin tamamen çökertilebileceği hissiyatıyla Suriye'ye taşınmıştır. ${ }^{8}$ PKK'nın 1980 askeri darbesinden yaklaşık bir ay kadar önce Suriye'ye geçiş sürecinde ve sonrasında da PKK'ya en büyük destek Şam yönetimi tarafından verilmiştir. Şam'daki ABD Büyükelçiliği yetkililerine göre, bu desteğin en önemli nedeni, Türkiye'nin Fırat Nehri üzerinde inşa ettiği Atatürk Barajı́nın Suriye'nin su kullanım hakkını azaltacağı ve hidroelektrik enerji üretimini sınırlayacağı korkusuydu. Tabii cumhuriyetin ilk yıllarında yaşanan Hatay sorunu da Şam'ın bilinçaltına ittiği bir gerçeklikti ve PKK’ya verilen desteğin tarihsel altyapılarından birisiydi.9 PKK'nın 1978'te kuruluşunu takip eden on yıllar boyunca, Türkiye'ye karşı sürdürülen terör faaliyetleri Hafız Esad tarafindan desteklenmiş ve PKK'nın Şam'da ofisler açmasına dahi izin verilmişti. ${ }^{10}$

Dönemsel şartlar bağlamında Suriye'deki kampların uçakla bombalanma ihtimali, Irak'taki kampların bombalanma olasılığından daha düşüktü. Bu nedenle örgüt yönetimi, militanlarını Türk ordusundan korumak için Suriye'deki kampları daha güvenli görmüştü. ${ }^{11}$ PKK’nın Suriye'de örgütlenme süreci iki yıl kadar devam etmiştir. Bu süreçte örgüt, Suriye'deki üslerini militanları için bir eğitim noktası olarak kullanmıştır. 1984 yılına gelindiğinde Türkiye'nin güneydoğu illerinde Türk güvenlik güçlerine ve sivillere yönelik saldırılar başlamıştır. 1984-1987 yılları arasındaki 3 yıllık süreçte 100'den fazla vatandaş ve asker şehit olmuştur. ${ }^{12}$

8 ABD, Merkezî İstihbarat Teşkilatı, Yayımlanmış Belgeleri (CIA-RDP): 87T00685R000200400003-1).

${ }^{9}$ CIA-RDP: 86T00587R000300300004-0.

${ }^{10}$ International Crisis Group, "Flight of Icarus? The PYD's Precarious Rise in Syria," Middle East Report, sayı: 151, (Belgium: 2014), 4-10.

${ }^{11}$ CIA/RDP: 87T00685R000200400003-1.

12 İbrahim Sarı, Kanl Terör Örgütü PKK: PKK Katliamları ve İsim İsim Arananlar, (Antalya: Net Medya Yayıncilık, 2017), 176-177. 


\section{Mustafa ÇALIŞKAN}

PKK tarafından sivillere yönelik birçok saldırıdan sadece 20 Haziran 1987'de gerçekleştirilen “Pınarcık Katliamı”nda; 16'sı çocuk, 6’sı kadın 30 sivil katledilmişti. ${ }^{13}$ Türkiye ise şiddetli saldırıları durdurmak amacıyla, Irak'taki kamplara karşı bir hava saldırısı düzenlemiş ve PKK'ya 50'den 335'e kadar değişen rakamlar arasında telaffuz edilen kayıplar verdirmiştir. 1986 öncesinde PKK’nın silahlı eylemleri, güvenlik devriyelerini tuzağa düşürmek ve sivilleri öldürmekle sınırlı kalmıştı. Ancak 1986 sonrasında, PKK daha sofistike saldırılar planlamıştır. Eylül ayında, Abdullah Öcalan tarafından imzalanan bir PKK broşüründe, Türkiye'de sabote edilecek hedefler listesine NATO ve ABD tesisleri de dâhil edilmiş ancak PKK tarafından 1986 Ekim ayında sadece Mardin'deki NATO radar tesisine saldırı yapılmıştı. ${ }^{14}$ Uluslararası tesisleri hedef alan bu tip sansasyonel

Üsküdar University Journal of Social Sciences, 2020; issue: 10 , 63-91 eylem fikri, PKK'nın adını tüm dünyaya duyurma ve gücünü gösterme ihtiyacının bir ürünü olarak ön plana çıkıyordu. ${ }^{15}$

Türkiye'nin idari sınırlarında filizlenen terörizm faaliyetlerine ek olarak, ASALA gibi PKK'yla ittifak yapan yabancı terör oluşumlarının faaliyetleri, hükümetlerin iç ve dış siyasal yaşamda karşılaştığı zorlukların artmasına neden oluyordu. İran ile Irak arasındaki savaş ve Lübnan'da yönetime karşı düzenlenen ayaklanmalar, Ortadoğu'dan Türkiye'ye kadar yayılan bir terörizm macerası üretmişti. Kürtçü ve Ermeni milliyetçisi terör örgütlerinin ittifakı, dış destekle ayakta durabilme yeteneğini elde edebilmesi, Türk hükümeti için ciddi bir endişe kaynağı olmuştu. Şam yönetimi her iki örgüte de eğitim kampı temin ediyor ve Türkiye'de terör faaliyetlerini organize edenlere para ve silah desteği sağlıyordu. PKK'nın saldırılarıyla eş zamanlı olarak Avrupa'da Ermeni terör örgütlerinin saldırıları da artmaya başlamıştır. PKK Türkiye'de iç güvenliği tehdit ederken ASALA ise yurtdışındaki Türkiye temsilciliklerini

\footnotetext{
${ }^{13}$ A.g.e., 123.

${ }^{14}$ CIA/RDP: 87T00685R000200400003-1.

${ }^{15}$ CIA/RDP: 87T00685R000200400003-1.
} 
Suriye'de PKK Faaliyetlerinin Tarihî Arka Planı ve PYD Terör Örgütünün Siyasallaşma Çabaları

tehdit etmekteydi. Bu nedenle ASALA ve Ermeni Soykırımı Adalet Komandoları (JCAG) tarafından yapılan saldırıları engellemek amacıyla, dış temsilciliklerde de güvenlik odaklı önlemlerin artırılması yoluna gidilmiştir. $^{16}$

Aradan geçen 18 yıl boyunca aralıksız devam eden saldırılar sonucunda, Türkiye'nin askeri harekât riskiyle karşı karşıya kalmış olan ve oluşan zor durumu bertaraf etmek isteyen Şam yönetimi, PKK militanlarını 1998 yılında topraklarından çıkarmaya başlamıştır. Suriye'den çıkartılan militanlar Irak'ın kuzeyinde Hakurk ve Kandil bölgesine yerleşirken, süreç Öcalan'ın Suriye'den çıkartılmasına ve Türkiye Cumhuriyeti tarafindan yakalanarak Türkiye'ye getirilmesine kadar devam etmiştir. ${ }^{17}$

\section{Suriye İç Savaşı ve PKK Parça Yapılanması YPG'nin Siyasallaşma Çabaları}

PKK Suriye'de bulunduğu süreçte, kendisini bölgeye hakim tek Kürt siyasi partisi olarak konumlandırmış ve 2003'te PYD’nin kurulmasına temel teşkil eden ilişkiler ağını örmüştür. 1980'lerde ve 1990’larda PKK, Suriye'de rejimin de izniyle Kürtçülügü şekillendiren tek örgüttü. 1987’ye kadar PKK, Şam, Kamışlı, Derik, Ras el Ayn, Afrin, Halep, Ayn el-Arab (Kobani) ve Haseke'de siyasi ofisler açmıştı. PKK, tarihsel olarak Cezire ve Haseke bölgelerinde faaliyet gösteren geleneksel Suriye Kürt siyasi partileri tarafından bırakılan Afrin, Ayn El-Arab ve Carablus bölgelerindeki büyük boşluğu doldurmayı başarmıştı. ${ }^{18}$

Suriye devlet başkanı Hafız Esad'ın 2000 yılında ölümüyle, yerine daha güçsüz bir karakter çizen Beşar Esad geçmiştir. Bu süreçte PKK, Abdullah Öcalan'ın talimatıyla Irak'ın kuzeyindeki PKK yapılanmasını Suriye'nin Kuzey'inde tekrar teşkil etmeye çalışmıştır. Bu talimat PKK’nın

\footnotetext{
${ }^{16}$ CIA-RDP: 85S00316R000200160005-8.

${ }^{17}$ Hariet Montgomery, Suriye Kürtleri, çev. Ümit Aydoğmuş (İstanbul: Avesta Yayınları, 2017), 187.

${ }^{18}$ Andrew Self ve James Michael Ferris, “Dead Men Tell No Lies,” 17.
} 


\section{Mustafa ÇALIŞKAN}

devletleşme isteği doğrultusunda ve adı dünyada terör faaliyetleriyle anılmayan yeni bir örgütlenme teşkil edilmek suretiyle şekillendirilmiştir. ${ }^{19}$

PYD’nin kuruluş kararı PKK'nın 2002'deki 8. Kongresinde alınmıştır. Türk istihbarat birimlerinin elde ettiği bilgilere göre, PKK’nın 8. Kongresinde PKK'nın “Serhildan” olarak adlandırdığı halk ayaklanmasını gerçekleştirmek istediği belirtilmiş ve örgüt 2003 yılında Kuzey Suriye’de "Demokratik Ortadoğu Federasyonu" adı altında partileşerek yeni bir ülke kurma amacına yönelmiştir. ${ }^{20}$

PYD'nin teşkilatlanmasını oluşturan temel kararlar, PKK'nın yönlendirmesiyle ve örgüt kontrolündeki terör kamplarında 2003'ten itibaren düzenlenen kongrelerle şekillendirilmiştir. Tunus'ta başlayan ve dünya kamuoyunda "Arap Baharı" olarak bilinen ${ }^{21}$ süreç, 2004 yılında Suriye'deki Baas rejiminin operasyonlarına karşı örgütlenmeye başlayan

Üsküdar University Journal of Social Sciences, 2020; issue: 10 , 63-91 YPG'nin 2011 yılında resmi olarak kuruluşunu ilan etmesi açısından çok önemli bir firsat olmuştur. Savaşla birlikte PYD’nin cephe kolu olan "Halk Savunma Birlikleri (YPG)” daha görünür hale gelmeye başlamış, kendisini Kuzey Suriye Federasyonu'nun resmi ordusu olarak tanımlamıştır. ${ }^{22} \mathrm{Bu}$ tanımlama, DEAŞ’a karşı mücadelede ve görünürde Suriye yönetimine destek amacıyla ortak düşmana karşı savaşma prensibi çerçevesinde şekillenmiş olup ${ }^{23}$ uluslararası platformlarda PYD-YPG'nin bilinirliğini artırmıştır.

19 Murat Köylü, "Suriye, PYD-YPG Yapılanması ve Zeytin Dalı Harekâtı," Assam Uluslararası Hakemli Dergi, sayı: 11, (2018): 70-86.

${ }^{20}$ Uğur Şevkat, “PKK kongresi: Amaç yeni ülke kurmak”, (NTV Arşiv) 8 Nisan 2002, http://arsiv.ntv.com.tr/news/146564.asp

${ }^{21}$ Mehmet S. Erol ve Kadir E. Çelik, “ABD’nin Suriye Politikasında Vekil Aktör Olarak Terör Örgütleri: YPG Örneği,” ANKASAM Bölgesel Araştırmalar Dergisi 2, sayı: 2, (2018): 14-45.

22 Beklan Kulaksızoğlu, "YPG PKK ile Ne Kadar Bağlantılı," (DW), 22 Ocak 2018, https://www.dw.com/tr/ypg-pkk-ile-ne-kadar-ba\%C4\%9Flant\%C4\%B11\%C4\%B1 /a-42261886

${ }^{23}$ Veysel Kurt, “Tunus, Misır, Libya ve Suriye: Orduların Arap Baharına Etkisi," Siyaset, Ekonomi ve Toplum Araştırmaları Vakfı (SETA), sayı: 102, (Temmuz, 2014): 7-21. 


\section{Suriye'de PKK Faaliyetlerinin Tarihî Arka Planı ve PYD Terör Örgütünün Siyasallaşma Çabaları}

Aslında Suriye yönetimi 2011 yılı öncesinde Kürt partileriyle birlikte, PYD’yi yasa dışı ilan etmiş ve lideri Salih Müslim’i Kuzey Irak'ta sürgünde iken ömür boyu hapis cezasına çarptırmıştı. 2011'deki ayaklanmanın patlak vermesinden kısa bir süre sonra Müslim, Suriye'ye geri dönmüş ve yanında yer alan bin civarında PKK'lı terörist ile YPG'yi kurduklarını ilan etmiştir. PYD’nin 2012'de Suriye'nin kuzeyinde ani yükselişi, partinin disiplini, organizasyonu ve çatışma dinamiğinden faydalanması bakımından dikkat çekicidir. Bunun en önemli nedeni PYD'nin PKK ile yakın ilişkileri ve gerekli eğitim, insan gücü ve silah tedarikinin PKK tarafından sağlanmasıdır. 2014 yılı itibariyle DEAŞ, Musul'u ele geçirerek İslam Devleti hilafetini ilan etmiş ve bunun üzerine Uluslararası Koalisyon Güçleri kurulmuştur. DEAŞ’ın Kürtlerin yoğun olarak yaşadığı bölgelere saldırması neticesinde DEAŞ ve YPG terör örgütleri arasında şiddetli sınır çatışmaları yaşanmıştır. ${ }^{24}$ Çatışmaların artması öncesinde PYD denetimindeki üç kantonun her biri, yürütme, yargı ve yasama konseyleri arasındaki bir güç dağılımı tarafından yönetiliyordu. Ocak 2011'de Suriye'nin Kuzeyinde Kürtçü örgütlenmeleri birleştiren ve örgütlerin şemsiye organizasyonunu oluşturduğunu iddia eden Demokratik Toplum Hareketi (TEV-DEM) 2014 yılına gelindiğinde kantonların yönetiminden sorumlu olduğunu ilan etmiştir. ${ }^{25}$

Koalisyon güçlerinin ve PYD’nin ortak düşmana karşı savaş verdiği algısının dünya kamuoyunda baskın bir şekilde tartışılması ise PYD’nin siyasal bir oluşum gibi algılanmasında etkili olmuştur. ${ }^{26} \mathrm{Bu}$ sırada, PYD-

\footnotetext{
${ }^{24}$ İbrahim Kerman ve Ertan Efegil, “Terör Örgütü Pkk/Pyd’nin Suriye’de İzlediği İç Savaş Stratejisinin Değerlendirilmesi,” ANKASAM Uluslararası Kriz ve Siyaset Araştırmaları Dergisi 1, say1: 2, (Ocak, 2017): 162-198.

${ }^{25}$ Burcu Özçelik, "Explaining the Kurdish Democratic Union Party's Self-Governance Practices in Northern Syria, 2012-2018”, (Cambridge: University Press, 2019), https:// doi.org/10.1017/gov.2019.1

${ }^{26}$ Verda Özer Arbil, Hurriyetdailynews, "PYD 'promised' US to not give arms to PKK" erişim 21 Kasım 2019, http://www.hurriyetdailynews.com/pyd-promised-us-to-notgive-arms-to-pkk-75307
} 


\section{Mustafa ÇALIŞKAN}

YPG, muhalifgruplara karşı "rejimin yanında yer alarak içeride rejimle olan bağlantısını renksizleştirmiş, dışarıda ise Rusya ile ilişkilerini bozmadan ABD'ye bağımlı” bir konuma oturmuştur. PYD'nin terör örgütü ve PKK parça yapılanması olduğu iddialarının hafifletilmesi amacıyla ve ABD'nin tavsiyesiyle TEV-DEM'in silahlı unsuru halindeki örgüt, adını Suriye Demokratik Güçleri (SDG) olarak değiştirerek iç savaşta siyasal kimlik dönüşümünde yeni bir aşamaya geçmiştir. ${ }^{27}$ PYD’nin SDG'ye dönüşümünün $A B D$ 'nin tavsiyesiyle gerçekleştiği ise bizzat $A B D$ Özel Kuvvetler Komutanı Raymond Thomas tarafindan doğrulanmıştır. ${ }^{28}$ PYD-YPG terör örgütü, “DEAŞ ile mücadele” iddiası üzerinden kontrol ettiği alanlarda özerk yapı oluşturma faaliyetlerine girişmiş ve bölgesel istikrarsızlıktan faydalanarak Suriye'nin kuzeyindeki toprakların bir

Üsküdar University Journal of Social Sciences, 2020; issue: 10 , 63-91 kısmına el koymuştur. ${ }^{29} \mathrm{Bu}$ el koymanın akabinde PKK-YPG terör örgütü, sivilleri öldürerek bölgedeki demografik düzeni kendi lehine değiştirmeye başlamıştır. ${ }^{30}$

2011 'de başlayan süreç, Suriye'nin kuzeyinde ve Suriye idari sınırlarının üçte birine denk gelen bölümünde, 2019 yılı itibariyle üç ayrı kantonun (Afrin-Kobani-Cezire) oluşturulmasına neden olmuştur. ${ }^{31}$ Suriye konulu çalışmalarda öncü araştırma merkezlerinin başında gelen Londra merkezli Kings College, Uluslararası Radikalleşme ve Siyasi Şiddet Araştırma Merkezi, ICSR (International Centre for the Study of Radicalisation

${ }^{27}$ Halil Atilla Sivrikaya, “Arap Baharı'nın Suriye Sahasında Arap Diline Olan Yansımaları: PYD/YPG Örneği”, Güvenlik Bilimleri Dergisi 8, sayı: 2, (Ankara: 2019): 334.

${ }^{28}$ Milliyet, “ABD istedi YPG isim değiştirdi," 22 Temmuz 2017, http://www.milliyet. com.tr/dunya/abd-istedi-ypg-isim-degistirdi-2488906

${ }^{29}$ İçişleri Bakanlığı, PKK/KCK Terör Örgütünün Suriye Kolu: PYD-YPG, (Ankara, 2017) https://www.icisleri.gov.tr/kurumlar/icisleri.gov.tr/IcSite/strateji/deneme/YAYINLAR/ \%C4\%B0\%C3\%87ER\%C4\%B0K/pyd_arapca.pdf

${ }^{30}$ Buğra Sarı ve Murat Tınas, "Terrorism Threat Against Humanity and Democracy: The PKK Case”, Polis Akademisi Yayınları, Rapor No: 17, Ankara, (Ağustos, 2018): 15.

${ }^{31}$ Anadolu Ajansı, “Türkiye'nin Terörle Mücadelesinde Barış Pınarı Harekâtı”, (İstanbul: Anadolu Ajansı Yayınları, 2019), 25-30. 
and Political Violence), PYD’yi Washington'un yenmeye isteksiz olduğu DAEŞ’e karşı sahaya sürülen bir taşeron olarak tanımlamaktadır. $\mathrm{Bu}$ tanımlamaya ek olarak PYD'nin Suriye'deki Sünni direnişiyle mücadelenin omurgası olduğunu ve Suriye iç savaşıyla birlikte baskın hale gelen siyasi bir aktör halini aldığı bazı araştırmalarda açıkça ifade edilmektedir. ${ }^{32} \mathrm{Bu}$ durum değerlendirildiğinde, Batı kamuoyunun Suriye iç savaşında yer alan tarafları DAEŞ’e karşı mücadele çerçevesinde değerlendirdiğine dair önemli bir örnek olarak ön plana çıkmaktadır.

\section{PKK ve PYD Terör Örgütlerinin Organik Bağı}

PKK militanlarının menşeine dair araştırmalarda, örgüt üyelerinden Suriyeli olanların oranının \%20-30 arasında olduğu ve Irak merkezli Kandil kampındaki toplam militan sayısının \%20 kadarının Suriyeli olduğu belirtilmektedir. PKK yöneticilerinden Cemil Bayı, PKK’nın kuruluşundan başlamak üzere 1.500 Suriyelinin PKK saflarında öldügünü belirtmiştir. Suriye'deki Kürt köylerinin neredeyse tamamından PKK’ya katılım sağlanmıştır. 2009 yılında Esad rejiminin, 1.500-2000 Suriyeli PKK üyesinin eve dönmesine izin verme niyetinde olduğunu belirtmesi ise resmi ağızdan açıklanan ilk verilerdendi. Hürriyet Gazetesi'nde Şubat 2012'de yapılan bir değerlendirmede, 2001'den 2011'e kadar öldürülen 1.362 PKK üyesinin yüzde 12,4'ünün Suriyeli olduğunu iddia eden istatistikler yayımlamıştır. Tüm bu rakamsal veriler PKK-PYD parça yapılanmasının bir anda ortaya çıkmadığını ve PYD'nin PKK içerisinde filizlendiğini ispatlayan önemli istatistiklerdir. ${ }^{33}$

PKK parça yapılanması PYD/YPG ilk kez Yargıtay 16. Ceza Dairesi'nin 21.05.2015 tarihli ve 2015/3513 E. 2015/1456 sayılı kararıla terör

\footnotetext{
${ }^{32}$ John Holland-McCowan, “The Kurds After the 'Caliphate': How the Decline of ISIS has Impacted the Kurds of Iraq and Syria,” ICSR, King's College, (London: 2018): 17-23. ${ }^{33}$ Barak Barfi, "Ascent of the PYD and the SDF," Hürriyet Gazetesi, Research Notes, The Washington Institute for Near East Policy, No. 32 Washington, (2016): 7-8.
} 


\section{Mustafa ÇALIŞKAN}

örgütü olarak kabul edilmiştir. ${ }^{34}$ Uluslararası arenada da PYD’yi örgüt olarak tanımlayan resmi kurum ve kuruluşlar bulunmaktadır. Ocak 2018'de Hollanda Parlamentosu'nda TSK'nın, Suriye'nin Afrin bölgesinde başlattığı Zeytin Dalı Harekâtı ile ilgili milletvekillerinin sorularını yanıtlayan Hollanda Dışişleri Bakanı Halbe Zijlstra, PYD’nin PKK ile sıkı bağlarının olduğunu belirtmiştir. ${ }^{35}$

2017 yılında, CIA'nın resmi internet sitesinde "Ülkelerin Görünüşleri" başlığı altında yer alan "Yabancı Kaynaklı Terörist Gruplar” listesinde Suriye'de faaliyet gösteren terör gruplarından birisi de PYD olarak belirtilmiştir. ${ }^{36}$ Merkezi Avrupa'da bulunan Uluslararası Kriz Grubu'nun raporunda, Suriye'deki terörist gruplar arasında PKK'nın bir alt örgütlenmesi olarak PYD gösterilmiştir. ${ }^{37}$

Üsküdar

University

Journal of Social Sciences, 2020; issue: 10 , 63-91

2016 yılının Mart ayında Mesud Barzani, "PYD ve PKK kesinlikle aynıdır” ifadesinde bulunurken, Amerika'nın Suriye'de PYD'ye desteğini "PKK'ya verilen destekle aynıdır" şeklinde ifade etmiştir. ${ }^{38}$ Barzani'nin beyanından hemen sonra, 2016 yılının Nisan ayında, ABD Senatosu'nun Silahlı Hizmetler Komitesi'nde Senatör Lindsey Graham'in Suriye konusunda sorularını cevaplayan ABD Savunma Bakanı Ashton Carter, YPG'nin PYD’nin silahlı kanadı olduğunu ve PYD ile PKK arasında ilişki olduğunu resmi olarak teyit etmiştir. ${ }^{39}$

\footnotetext{
${ }^{34}$ Yargitay 16. Ceza Dairesi, Karar No: 2015/3513 E. 2015/1456, 21.05.2015.

35 Euronews, "Introduction: SYRIA," (2018), https://tr.euronews.com/2018/01/24/ hollanda-d-sisleri-bakan-halbe-zijlstra-ypg-masum-degil

${ }^{36}$ CNN Türk, "PYD CIA'in internet sitesinde yabancı terör örgütleri listesinde," (28 Ocak 2018), https://www.cnnturk.com/dunya/pyd-ciain-internet-sitesinde-yabanci-terororgutleri-listesinde

${ }^{37}$ International Crisis Group, "Flight of Icarus? The PYD’s Precarious Rise in Syria”, Middle East Report, No: 151, (Belgium: 2014): 4-10.

${ }^{38}$ Hürriyet, “Barzani: PKK ile PYD aynıdır,” (23 Mart 2016), http://www.hurriyet.com. tr/gundem/barzani-pkk-ile-pyd-aynidir-40074445

${ }^{39}$ Anadolu Ajansı, Türkiye’nin Terörle Mücadelesinde Barış Pınarı Harekâtı, 54-55.
} 
PKK/PYD/YPG diğer terör örgütleri gibi kendilerine militan devşirirken yetişkin-çocuk ayrımı yapmamışlardır. Milletler Cemiyeti tanımlamasına göre "Çocuk" uluslararası ve ulusal hukuk açısından 18 yaş altında olan kişi olup, 1948 İnsan Hakları Evrensel Beyannamesi, 1949 Cenevre Sözleşmeleri, 1950 Avrupa İnsan Hakları Sözleşmelerine göre çocukların savaş amacıyla kullanılması yasaklanmıştır. Buna karşın, PKK ve PYD örgütlerinin her ikisinde de küçük yaşta çocuklar kullanılmaktadır. Birleşmiş Milletler, PKK safları içinde çocuk savaşçılar bulunduğunu ve PKK’nın 1994 yılından beri sistematik bir şekilde çocukları çatışmalarda kullandığını belirtmiştir. ${ }^{40}$ Aynı şekilde YPG içerisinde de uluslararası sözleşmelere aykırı olarak çocuklar kullanılmaktadır. ${ }^{41}$ Birleşmiş Milletler Genel Sekreterliği’nin, "Silahlı Çatışmalarda Çocuklar” Özel Temsilcisi Virgina Gamba'nın, terör örgütü PYD-SDG üyesi terörist ile BM Cenevre Ofisi'nde, örgütün çocuk savaşçıları serbest bırakması eylem planına 29 Haziran 2019 tarihinde resmi törenle imza atması YPG içerisinde çocuk savaşçıların kullanıldığını resmi olarak ispatlamaktadır. ${ }^{42}$

Europol 2019 raporunda, 2002'den başlamak üzere AB'nin terör örgütleri listesinde yer alan PKK’nın AB'de “Organize suça karıştığı ve uyuşturucu ticareti yaptığı” vurgulanmıştır. ${ }^{43}$ YPG’nin finansmanı ise

${ }^{40}$ Serkan Kekevi ve Gökmen Kılıçoğlu, "Uluslararası Hukuk Açısından Çocuk Askerler ve PKK’nın Çocuk Askerleri/Militanları,” Ankara Barosu Dergisi, sayı: 3, (2016): 489495.

41 T.C. Madrid Büyükelçiliği, PKK-PYD İlişkisi: PYD’nin Suriye’deki Etnik Terör Uygulamaları, (Nisan 2017), 9, http://madrid.be.mfa.gov.tr/Content/assets/consulate/ images/localCache/1/e1d230a8-eea8-44a0-8fac-c37f2c4453fb.pdf

42 Ünal Atabay, “Birleşmiş Milletler' in YPG ile İmzası “Çocuk Savaşçılar,” 21. Yüzyıl Türkiye Enstitüsü, Milli Güvenlikve Dış Politika Araştırmaları Merkezi, (6 Temmuz 2019), https://21yyte.org/tr/merkezler/islevsel-arastirma-merkezleri/milli-guvenlik-ve-dispolitika-arastirmalari-merkezi/birlesmis-milletler-in-ypg-ile-imzasi-cocuk-savascilar ${ }^{43}$ Europol, "EU Drug Markets Report,” (Hollanda: 2019), 35-36, http://www.emcdda. europa.eu/system/files/publications/12078/20192630_TD0319332ENN_PDF.pdf 


\section{Mustafa ÇALIŞKAN}

PKK tarafından uyuşturucu ticaretinden elde edilen gelirler ve Suriye'nin sahip olduğu petrol kuyularından çıkarılan petrolün pazarlanmasıyla sağlanmaktadır. Bu bağlamda, zengin petrol kaynaklarına sahip olmasından dolayı Suriye'nin kuzeyindeki Kamışlı Bölgesi örgütün en fazla önem verdiği yerlerdendir. ${ }^{44}$

Terör örgütü YPG/PKK ile defalarca müzakere masasına oturan ve çok alanda iş birliği yapan Esad yönetimi, 2019 Eylül ayında Birleşmiş Milletlere gönderdiği mektupta, SDG için (YPG/PKK) "ayrılıkçı terör örgütü” ifadesini kullanmıştır. Mektupta, SDG’nin “Suriye halkına karşı Batılı ülkelerle ortak hareket ettiği” belirtilirken, örgütün Suriye halkına yönelik insan hakları ihlallerinde bulunduğu belirtilmiştir. ${ }^{45}$

Üsküdar

University Journal of Social Sciences, 2020; issue: 10 , 63-91

Tüm bunlara ek olarak Dünya kamuoyunda DEAŞ’a karşı mücadele verme söylemi bağlamında siyasallaştırılan, PYD’nin PKK'nın Suriye kolu olduğunun önemli ispatları aşağıda maddeler halinde sunulmuştur:

1. Abdullah Öcalan'nn, 1997'de Ayn El-Arab (Kobani) Bölgesini ziyaret etmesi ve o andan itibaren Suriyeli Kürtlerin onu takip etmeye başlaması,

2. PYD yöneticilerinin, Kandil'de ideolojik eğitim almış olmaları ve Suriye iç savaşı yaşanırken, Kandil bölgesinden Suriye'nin Kürt bölgelerine geri dönmüş olmaları, ${ }^{46}$

3. Abdullah Öcalan' 'n, Şubat 2002'de PKK yönetiminden, Suriye'de 'Suriye Kürtlerinin Birlik Partisi' kurulmasını istemesi, Suriye'de PYD adı altında örgütlenmeye gidilmesi, ${ }^{47}$

4. YPG'nin Öcalan'ın liderliğini kabul etmesi, ideolojik programına kendini adaması ve PYD’nin savaşçı grubu YPG'nin Kandil liderliğini tanıması, ${ }^{48}$

${ }^{44}$ Can Acun ve Bünyamin Keskin, PKK'nın Kuzey Suriye Örgütlenmesi: PYD-YPG, (İstanbul: Turkuaz Matbaacilık, 2016), 26.

${ }^{45}$ Anadolu Ajansı, Türkiye'nin Terörle Mücadelesinde Barış Pınarı Harekâtı, 54.

${ }^{46}$ International Crisis Group, "Flight of Icarus? The PYD's Precarious Rise in Syria," 4-10.

${ }^{47}$ A.g.e., 4-10.

${ }^{48}$ Hürriyet, “ABD’li komutanın general dediği PKK'lı!” (6 Mart 2018), http://www. hurriyet.com.tr/gundem/abdli-komutanin-general-dedigi-pkkli-40762427 


\section{Suriye'de PKK Faaliyetlerinin Tarihî Arka Planı ve PYD Terör}

Örgütünün Siyasallaşma Çabaları

5. SDG'nin sözde komutanı Mazlum Kobani kod adlı Ferhat Abdi Şahin'in PKK örgütünün yöneticisi Abdullah Öcalan' 'n manevi oğlu olması, ${ }^{49}$

6. Irak idari sınırlarında, PKK tarafindan kullanılan Kandil Kampı'nın, PYD’nin ana karargâhı olarak kullanılmış olması, ${ }^{50}$

7. PKK Yürütme Konseyi üyesi Mustafa Abdi Bin Halil'in, PYD’nin faaliyetlerinin sorumlusu olarak görevlendirilmesi. ${ }^{51}$

8. Öcalan'ın 'demokratik özerklik' yaklaşımına vurgu yapılarak, KCK Rojava'nın kurulduğunun PYD tarafindan ilan edilmesi.

9. PYD terör faaliyetlerinin PKK'nın Kandil bölgesinde bulunan komuta ve kontrol yapılanması altında yürütülmesi, ${ }^{52}$

10. PKK ile PYD yöneticileri arasındaki ilişkinin PKK'nın Suriye'deki Kürtler arasında taban oluşturduğu 1980'li yıllara dayanması, ${ }^{53}$

11. Öcalan ile irtibatlı Salih Muhammed Müslim'in, ilk PYD Başkanı Barazani Muhammed'in yerine başkan seçilmesi ${ }^{54}$

12. İlk PYD lideri Barazani Muhammed ile hali hazırdaki lider Salih Muhammed Müslim'in PKK liderlerinden Murat Karayılan ve Abdullah Öcalan ile geçmişe dayanan ilişkilerinin mevcut olması, ${ }^{55}$

13. PKK/KCK Suriye Üst Yönetimi Dış ilişkiler Sorumlusu ve PKK Merkez Komite Üyesi olan Velid Halil'in, 2012 yllında Suriye'deki faaliyetlerin çatı organizasyonu olan TEV-DEM Koordinasyon üyeliğine getirilmiş olmass,${ }^{56}$

${ }^{49}$ Ferhat Abdi Şahin Türkiye tarafından kırmızı kod ile aranan PKK militanları arasında yer almakta olup PYD içerisinde sözde komutan ilan edilmeden önce "Şahin Cilo" kod adını kullanmıştır (Hürriyet, “ABD’li komutanın general dediği PKK'lı!”

50 T.C. Madrid Büyükelçiliği, PKK-PYD İlişkisi: PYD’nin Suriye’deki Etnik Terör Uygulamaları, 9.

${ }^{51}$ A.g.e.

${ }^{52}$ A.g.e.

${ }^{53}$ A.g.e.

${ }^{54}$ A.g.e.

${ }^{55}$ A.g.e.

${ }^{56}$ Bayram A. Soner, Ömer Aslan ve Hakan Kıyıcı, PKK's Regional Franchise of Terror, Uluslararası Terörizm ve Güvenlik Araştırmaları Merkezi Utgam, (Ankara, Melek Matbaası: 2017), 18. 1-43. 


\section{Mustafa ÇALIŞKAN}

14. 1998 yılında PKK terör örgütüne katılan İlham Ahmed'in, örgütün Suriye yapılanmasına katılmadan önce Kandil alanında PJAK yönetiminde faaliyet göstermiş olması ve PKK/KCK mensubu Şahin Cilo (K) Mustafa Abdi Bin Halil'in yardımcısı olarak görevlendirilmesi, ${ }^{57}$

15. TEV-DEM Yürütme Konseyi üyesi olan Hanife Hüseyin 2012 yllında PYD'nin kadın kolları yapılanması Star Birlik Grubu Koordinasyon üyesi olması. 2013 yılı içerisinde KCK Yürütme Kurulu ve PKK Merkez Komite üyeliğine seçilen Hanife Hüseyin'in, halihazırda Suriye'de YPG içerisindeki tüm kadın kollarından sorumlu olarak faaliyet yürütüyor olmasidir. $^{58}$

\section{Tablo 1: Terör Örgütü PKK/KCK'nın Parça Örgütlenmesi: PYD/YPG'nin Suriye Yapılanmas ${ }^{\natural 9}$}

Üsküdar

University

Journal

of Social

Sciences, 2020;

issue: 10 ,

63-91

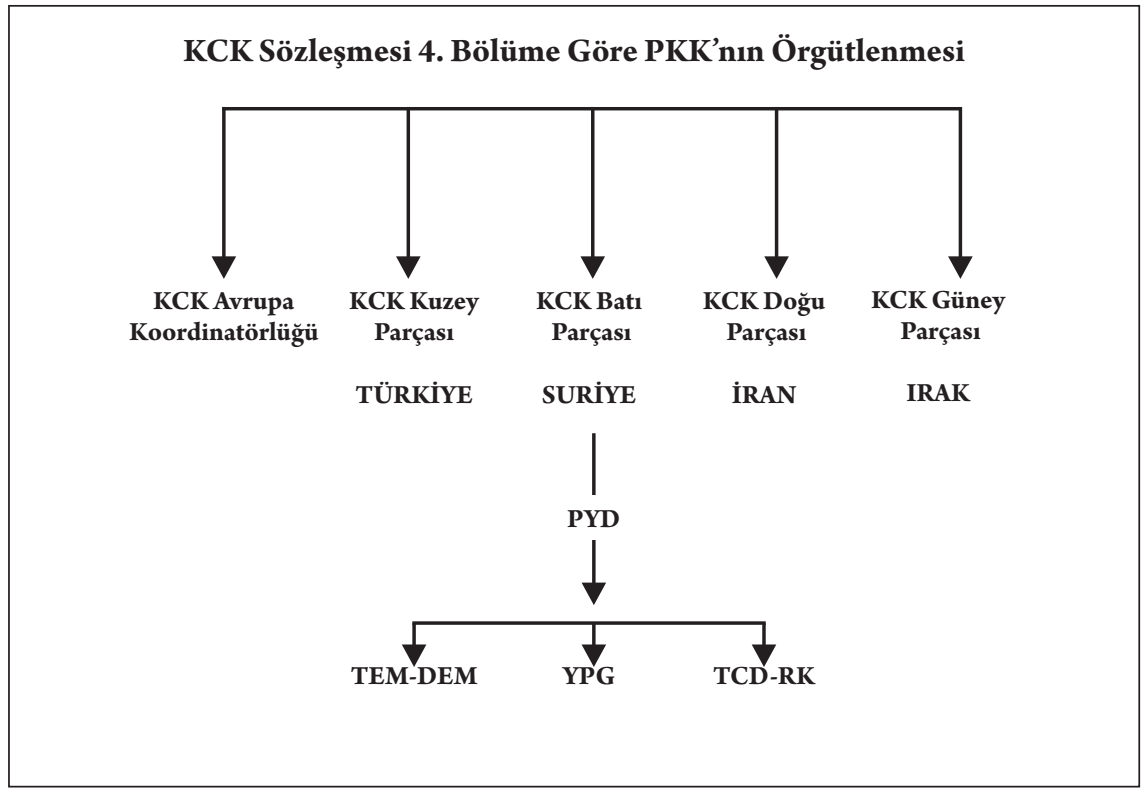

${ }^{57}$ A.g.e., 1-43.

${ }^{58}$ İçişleri Bakanlı̆̆ı, PKK/KCK Terör Örgütünün Suriye Kolu: PYD-YPG, 20.

${ }^{59}$ A.g.e., $20-21$. 
Suriye’de PKK Faaliyetlerinin Tarihî Arka Planı ve PYD Terör Örgütünün Siyasallaşma Çabaları

Maddeler halinde sıralanan bu hususlar PKK ve PYD arasındaki bağı ispatlamakla birlikte sunulan (Tablo 1 ve Tablo 2) örgütlerin kuruluş bildirileri ve yönetimsel özellikleri her iki örgütün de tek bir merkezden yönetildiğini göstermektedir. PYD tüzügünde PKK terör örgütü lideri Abdullah Öcalan'a atıf yapılması bile başlı başına PYD’nin de terör örgütü olduğunun bir göstergesidir. Buna ek olarak aşağıda sunulan KCK sözleşmesi ve PKK-PYD tüzüklerinde yer alan ifadeler ve örgütün yönetim şeması (bkz:: Tablo 1, Tablo 2 ve Tablo 3) PYD’nin PKK terör örgütünün Suriye kolu olduğunu ispatlar niteliktedir.

\section{Tablo 2: KCK Sözleşmesi ile PKK ve PYD Tüzüklerinde Yer Alan Ana Hususlar. ${ }^{60}$}

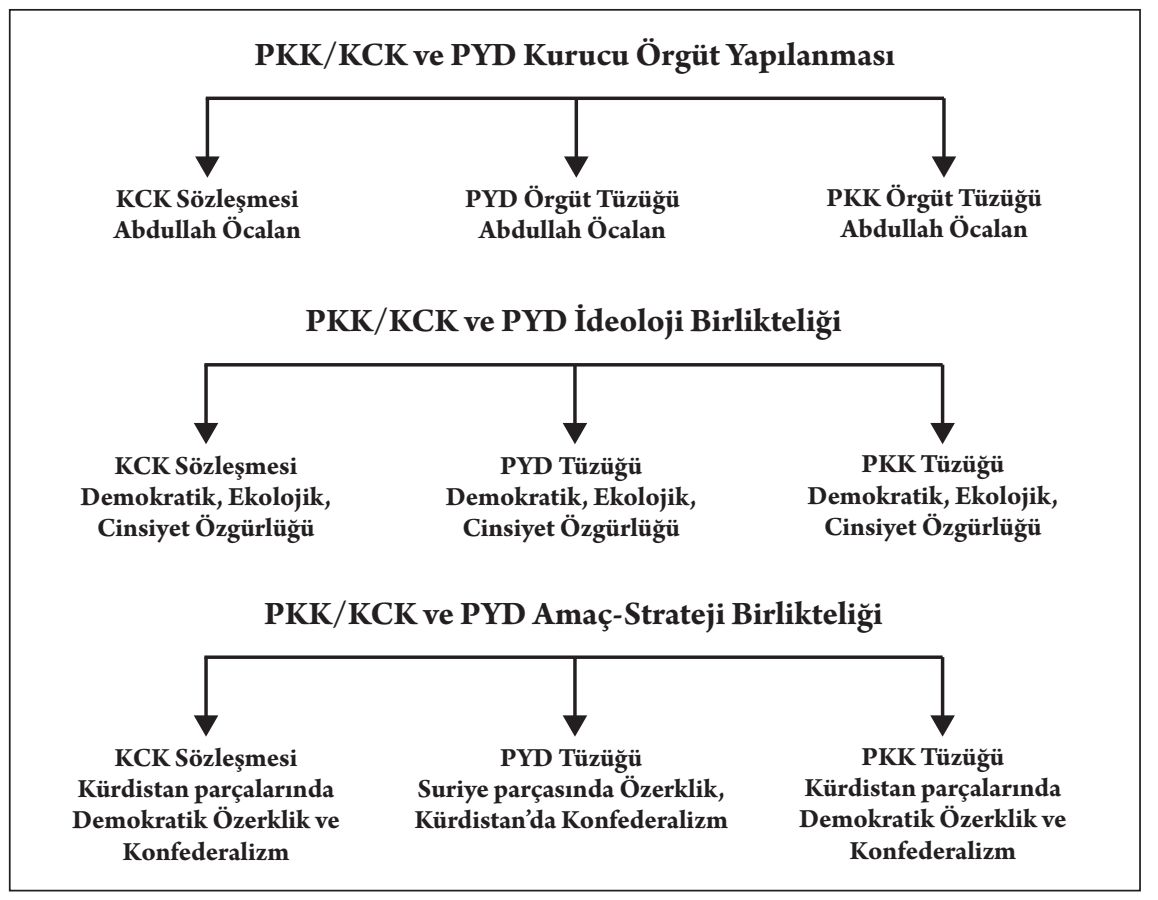

${ }^{60}$ A.g.e., 20. 


\section{Mustafa ÇALIŞKAN}

Tablo 1'de görüleceği üzere KCK sözleşmesinde PYD örgüt tüzügünde ve PKK örgüt tüzügünde kurucu lider Abdullah Öcalan adı geçmektedir. Buna ek olarak ideolojik ve amaç strateji birliği bakımından da yüzde yüz oranına yakın bir benzerlik söz konusudur. Aşağıda sunulan Tablo 2'den de tüzük benzerliğinin içeriği daha net gözlemlenebilmektedir.

Tablo 3: PKK/KCK ve PYD'nin Kuruluş Tüzükleri' ${ }^{11}$

Üsküdar

University

Journal of Social

Sciences, 2020; issue: 10 ,

63-91

\section{\begin{tabular}{l|l} 
PKK Tüzüğ̈̈ & PYD Tüzüğüi
\end{tabular}}

\begin{tabular}{|c|c|}
\hline PKK Tüzüğü & PYD Tüzüğü \\
\hline Parti Lideri: Abdullah Öcalan & PYD Lideri: Abdullah Öcalan \\
\hline $\begin{array}{c}\text { Kongre partinin en yüksek karar } \\
\text { organıdır. }\end{array}$ & $\begin{array}{c}\text { Kongre partide en yüksek karar } \\
\text { organıdır. }\end{array}$ \\
\hline $\begin{array}{l}\text { Önderliğin istemi veya parti } \\
\text { meclisinin üçte ikisinin kararı ya da } \\
\text { kadro sayısının üçte birinin istemiyle } \\
\text { zamanından önce toplanabilir. }\end{array}$ & $\begin{array}{l}\text { Kongre parti başkanının onayıyla ya da } \\
\text { parti yürütme komisyonu üyelerinin } \\
\text { kararıyla vaktinden önce toplanabilir. }\end{array}$ \\
\hline $\begin{array}{l}\text { Yine Önderliğin istemi ve parti } \\
\text { meclisinin üçte ikisinin kararıla bir } \\
\text { defaya mahsus olmak üzere en fazla } \\
1 \text { yll ertelenebilir. }\end{array}$ & $\begin{array}{l}\text { Ayrıca parti başkanının isteğiyle ve } \\
\text { encümenliğin üyelerinin istemiyle bir } \\
\text { seferliğine mahsus } 1 \text { yıl uzatılabilir }\end{array}$ \\
\hline $\begin{array}{l}\text { Parti kadrosu (üyesi), kendini } \\
\text { Apocu tarz, tempo ve üsluba } \\
\text { ulaştırarak parti amaçları için } \\
\text { yürüttügü mücadele ile yoldaşlarına } \\
\text { ve tüm topluma örnek olan kişidir. }\end{array}$ & $\begin{array}{l}18 \text { yaşını dolduran kişi, lider Apo’nun } \\
\text { demokratik uygarlık çizgisine inanan, } \\
\text { parti programına ve yönetmeliğine } \\
\text { inanır ve yaşamına uygular. }\end{array}$ \\
\hline $\begin{array}{c}\text { Parti Kadrosunun Görevleri: Lider } \\
\text { Aponun yaşamını ve özgürlügünü } \\
\text { benimsemelidir. Apocu çizgiyi } \\
\text { özümsemelidir. }\end{array}$ & $\begin{array}{l}\text { Parti Üyelerinin Amaçları: Kürt halkı } \\
\text { lideri Abdullah Öcalan’a bağlllı̆̆ı } \\
\text { şeref bilmeli ve onun özgürlüğü için } \\
\text { mücadele etmelidir. Demokratik } \\
\text { konfederalizm sisteminin oluşmasi için } \\
\text { çaba göstermelidir. }\end{array}$ \\
\hline
\end{tabular}

${ }^{61}$ A.g.e., 23-27. 


\section{Sonuç}

PKK 1980'li yıllardan başlamak üzere Türkiye'de örgütlenme aşamalarını sürdürmüş ve 1980 askeri darbesinden hemen önce Suriye idari sınırlarına geçerek örgütün taktik eğitim faaliyetlerine devam ederken bir taraftan da ideolojik yapılanmasını devam ettirmiştir. Bu süreçten sonra Suriye, Türkiye'ye yönelik saldırıların yönetildiği ana merkez olmuştur. Suriye'nin teröre verdiği destek sonucunda Suriye'de örgütlenen terör grupları Suriye iç savaşının çıkmasını firsat bilerek Suriye'nin toprak bütünlügünü tehdit etmeye başlamışlardır. Suriye'de yaklaşı 40 yıl boyunca faaliyetine devam eden PKK, dünyanın hemen hemen tüm ülkelerinde terörist gruplar arasında yer aldığından Suriye'deki iç savaş öncesi komşu devletlerin meşru müdahale haklarını engelleyebilmek amacıyla farklı isimler altında örgütlenme çabasında olmuştur.

Suriye iç savaşı sırasında oluşan otorite boşluğunu firsata çevirmek amacıyla harekete geçen PKK, DEAŞ’la mücadele mottosunu öne sürerek örgütün Suriye kolu olan PYD adı altında örgütsel faaliyetlerini sürdürmeye başlamıştır. DEAŞ terör örgütüyle mücadele kapsamında ele geçirdiği bölgelerde idari yönetim bölgeleri oluşturarak bağımsızlık hedefleyen PKK/PYD, örgütsel faaliyetlerini tüm dünya kamuoyunda terör örgütü olarak tanımlanan DEAŞ’a karşı mücadele ettiği fikri üzerine inşa etmiştir.

İki terör oluşumundan birisini diğerine tercih etme eğilimiyle hareket eden dünya kamuoyu ise PYD’yi meşrulaştırma çabasında olmuştur. PKK'nın yönetim kadrolarında yer alan ve Suriye iç savaşıyla birlikte kuruluşunu ilan eden PYD'ye katılan örgüt mensupları, YPG’nin PKK talimatlarıyla örgütsel faaliyetlerini sürdürdügünün en açık göstergelerinden birisidir. PKK ve PYD'nin kuruluş bildirgeleri ve örgütsel yapılanmaları yüzde yüze yakın benzerlik göstermekte olup, çalışmada öne sürülen benzerlikler PYD parça yapılanmasının, PKK’nın Suriye üzerinde parça örgüt olarak terörizm faaliyetlerini sürdürdüğünü 


\section{Mustafa ÇALIŞKAN}

açıç̧a ispatlamaktadır. Özellikle her iki örgütün tüzüklerinde lider olarak Abdullah Öcalan'ın yer alması yönetimsel benzerliğin en bariz örneğini oluşturmaktadır.

PKK/KCK terör örgütü, örgüte militan ve üye sağlamak amacıyla 1980'li ylllardan başlamak üzere Suriye'den örgüte eleman temini ve PKK’nın; İran, Irak, Suriye ve Türkiye'yi kapsayan "Dört parçalı Kürdistan” hayalinin hayata geçirilmesi hedefi, PKK ve PYD arasındaki en sağlam ideolojik bağ konumundadır. 2011 yılından itibaren Suriye'de güç dengeleri değişip mevcut yönetimin meşruiyeti tartışma konusu olunca PKK, Suriye topraklarında PYD parça örgütlenmesini görünür hale getirip dünya kamuoyunda meşruiyet kazanma çalışmalarına başlamıştır. Arap Baharı sonrasında Suriye iç savaşıyla ortaya çıkan demografik hareketlilik,

Üsküdar University Journal of Social Sciences, 2020; issue: 10 , 63-91 Suriye'nin sınır komşuları başta olmak üzere birçok devleti birinci derecede etkilemiştir. $\mathrm{Bu}$ demografik hareketlilik, terörizm kaynaklı olup, terör gruplarının Irak ve Suriye idari sınırlarında devletleşme hedefleri doğrultusunda şekillenmiştir. Suriye toprakları üzerinde terörist grupların devlet oluşumu sürecine girmeleri bir taraftan Suriye'nin toprak bütünlügünün ihlaline neden olurken, diğer taraftan DEAŞ ve PYD'nin aynı anda devletleşme ideolojisiyle harekete geçmeleri dünya kamuoyunda bir terör örgütüne karşı diğer terör örgütünün savunulması gibi, pek karşılaşılmayan bir durumu ortaya çıkarmıştır. PYD’nin DEAŞ’e karşı savaştı̆̆ konusunun dünya kamuoyunda sıklıkla işlenmesi ise PYD’nin siyasi bir aktör gibi algılanmasına ve dünya kamuoyunda bölgesel bir güç olarak benimsenmesine neden olmuştur.

\section{Kavram ve Tanımlar}

Bu çalışmada kullanılan örgüt isimlerinin kısaca açıklanması örgütsel terminolojinin kavranmasına fayda sağlayacağından öncelikle terör, terörizm ve bu kavramlar bağlamında faaliyet gösteren örgütlere kısaca değinilmiştir. Bu kavramlardan başlıcaları terör ve terörizm olup çalışmada adı geçen ve bu faaliyetleri sürdüren örgütler aşağıda sıralanmıştır: 


\section{Suriye'de PKK Faaliyetlerinin Tarihî Arka Planı ve PYD Terör Örgütünün Siyasallaşma Çabaları}

Terör, korkutma, yıldırma ve tedhiş, yoğunluk olarak büyük çapl, birey ya da bireylerin ruhsal yapılarını birdenbire kaplayan korku durumunu ve şiddet halini ifade etmektedir. ${ }^{62}$ Her devletin terör kavramını yorumlaması, devlet güvenliği özelinde farklı ana hatlar üzerine kurgulanabileceğinden terör kavramının evrensel tanımlamasının yapılması mümkün değildir. Türk Dil Kurumu (TDK) sözlügüne göre “Terörizm” siyasi unsuru içeren, yani bir ideolojisi bulunan ve mevcut sistemi şiddet yolu ile tahribe yönelmiş olma durumunu ifade etmektedir. ${ }^{63}$

"Homegrown" Terörizm ise literatürde radikal fikirleri benimseyen, ancak radikal terör örgütleriyle sadece ideolojik bağı olan teröristler için kullanılmaktadır.64 Çalışmada değinilen terör örgütleri ve cephe uzantılarının kısaltmaları aşağıda yer almaktadır: ${ }^{65}$

ASALA: Armenian Secret Army for the Liberation of Armenia Ermenistan'ın Kurtuluşu için Ermeni Gizli Ordusu

${ }^{62}$ Ahmet Taner Kışlalı, Siyasal Sistemler Siyasal Uzlaşma ve Çatışma, (Ankara: İmge Kitabevi 2000), 18.

${ }^{63}$ Tamer Kaşıçç, "Küresel Terörizm ve Birleşmiş Milletler Sistemi”, The Turkish Yearbook of International Relations, Vol. 47, (2016): 1-21. "Bir ideoloji etrafında örgütlenen birden fazla kişinin, şiddet eylemleri temelinde mevcut siyasal iktidarı ve rejimi hedef alan" faaliyetleri terörizm olarak adlandırılır. Hedef alınan rejimin veya sistemin şiddet yolu ile yıkılarak, yerine kendi örgüt ideolojileri doğrultusunda yeni bir yönetim tesis etmek terörizmin en büyük hedeflerinden birisidir. Siyaset bilimci Ahmet Taner Kışlalı, terörizmin amacını, toplumun ve dolayısıyla toplumu yönetenlerin direncini kırmak için "ortak korku yaratmak," daha doğrusu "dehşet salmak" ifadesiyle tanımlamaktadır (Kışlalı, Siyasal Sistemler Siyasal Uzlaşma ve Çatışma, 18); Bu tanım BM 49/60 sayılı genel kurul kararını kapsayıcı olup "Uluslararası Terörizmden Kurtulmak için Önlemler Hakkında Deklarasyon” un 2. Maddesinde "politik amaçlarla kamuoyunda bir terör durumu yaratmaya yönelik tüm kriminal eylemlerin gayri-meşrudur” ifadesiyle benzerlik göstermektedir (Kaşıkı, "Küresel Terörizm ve Birleşmiş Milletler Sistemi, 5).

${ }^{64}$ Crone Manni ve Martin Harrow, "Homegrown Terrorism in The West 1989-2008", Danis Institute For International Studies (DIIS), Cophanengen (2008), 5-6.

${ }^{65}$ Andrew Self ve James Michael Ferris, “Dead Men Tell No Lies,” 12. 


\section{Mustafa ÇALIŞKAN}

DEAŞ: Devletu'l Islamiyye fi'l Irak ve'ş Şam - Irak ve Şam İslam Devleti.

JCAG: Justice Commandos of the Armenian Genocide - Ermeni Soykırımı Adalet Komandoları.

KDP-I: Kürdistan Demokrat Partisi Irak.

KDP-İ: Kürdistan Demokrat Partisi İran.

KDP-S: Kürdistan Demokrat Partisi Suriye.

KDP-T: Kürdistan Demokrat Partisi Türkiye.

PKK: Partiya Karkerên Kurdistane - Kürdistan İşçi Partisi.

PKK-KCK: Koma Civakên Kurdistan - Kürdistan Topluluklar Birliği. PKK’nın 5. Genel Kurul Toplantısında (16-22 Mayıs 2007),

Üsküdar

University

Journal

of Social

Sciences, 2020;

issue: 10 ,

63-91
PKK’ya ek olarak Kürdistan Topluluklar Birliği (KCK) ismi

kabul edilmiş ve izleyeceği politikalar belirlenmiştir.

PYD: Partiya Yekîtiya Demokrat - Demokratik Birlik Partisi.

SDG: Suriye Demokratik Güçleri.

TEV-DEM: Tevgera Civaka Demokratîk - Demokratik Toplum

Hareketi.

YPG: Yekîneyên Parastina Gel - Halk Koruma Birlikleri.

YPJ: Yekîneyên Parastina Jin - Kadın Koruma Birlikleri.

YTS: Yabancı Terörist Savaşçlar. ${ }^{66}$

PJAK: Partiya Jiyana Azad a Kurdistane - Kürdistan Özgür Yaşam Partisi.

HPG: Hêzên Parastina Gel - Halk Savunma Güçleri 
Suriye’de PKK Faaliyetlerinin Tarihî Arka Planı ve PYD Terör Örgütünün Siyasallaşma Çabaları

\section{KAYNAKÇA}

ABD, Merkezî İstihbarat Teşkilatı, Yayımlanmış Belgeleri (CIA-RDP). CIA-RDP-85S00316R000200160005-8;CIA-RDP-6T00587R00030030 0004-0; CIA-RDP-87T00685R000200400003-1.

Acun, Can ve Bünyamin Keskin. PKK'nın Kuzey Suriye Örgütlenmesi: PYD-YPG. İstanbul: Turkuaz Matbaacılık, 2016.

Anadolu Ajansı. "ABD Savunma Bakanı PKK ile YPG ve PYD ilişkisini kabul etti.” Erişim 6 Aralık 2019, (2016), https://www.aa.com.tr/ tr/dunya/abd-savunma-bakani-pkk-ile-ypg-ve-pyd-iliskisini-kabuletti/563312

Anadolu Ajansı. "Esed rejiminden BM'ye YPG/PKK "ayrılıkçı terör örgütü” mektubu.” (2019), Erişim 6 Aralık 2019, https://www.aa.com. $\mathrm{tr} / \mathrm{tr} /$ dunya/esed-rejiminden-bmye-ypg-pkk-ayrilikci-teror-orgutumektubu-/1584814

Anadolu Ajansı. "Pentagon Suriye'deki petrol gelirlerinin YPG/PKK'ya gittiğini itiraf etti.” (2019), Erişim 9 Aralık 2019, https://www.aa.com. $\mathrm{tr} / \mathrm{tr} /$ dunya/pentagon-suriyedeki-petrol-gelirlerinin-ypg-pkkya-gittiginiitiraf-etti/1638782

Anadolu Ajansı. Türkiye’nin Terörle Mücadelesinde Barış Pınarı Harekâtı. Anadolu Ajansı Yayınları, Kasım 2019.

Atabay, Ünal. Birleşmiş Milletler' in YPG ile İmzası “Çocuk Savaşçılar” 21. Yüzyıl Türkiye Enstitüsü, Milli Güvenlikve Dış Politika Araştırmaları Merkezi. (2019), Erişim 18 Aralık 2019, https://21yyte.org/tr/merkezler/islevselarastirma-merkezleri/milli-guvenlik-ve-dis-politika-arastirmalarimerkezi/birlesmis-milletler-in-ypg-ile-imzasi-cocuk-savascilar

Ayabakan, Levent. “Kürt-İngiliz İlişkileri 1918-1923.” Yayımlanmamış Doktora Tezi, Sakarya Üniversitesi Sosyal Bilimler Enstitüsü, Sakarya, 2016. 


\section{Mustafa ÇALIŞKAN}

Barfi, Barak. "Ascent of the PYD and the SDF." Research Notes, The Washington Institute for Near East Policy, 32, (Washington, 2016): 1-21. CIA, “The World Factbook.” (2019), Erişim 14 Kasım 2019, https:// www.cia.gov/library/publications/resources/the-world-factbook/geos/ print_sy.html

CNN Türk. "PYD CIA'in internet sitesinde 'yabancı terör örgütleri' listesinde.” (2018), Erişim 14 Kasım 2018, https://www.cnnturk.com/ dunya/pyd-ciain-internet-sitesinde-yabanci-teror-orgutleri-listesinde

Crone, Manni ve Martin Harrow. "Homegrown Terrorism in The West 1989-2008." Danis Institute For International Studies (DIIS),

Üsküdar University Journal of Social Sciences, 2020; issue: 10 , 63-91 (Cophanengen: 2008): 1-22.

Demir, Hilmi. "Yabancı Savaşçılar ve Homegrown Teröristler." Türkiye Ekonomi Politikaları Araştırma Vakfı, Değerlendirme Notu, Mart 2015, https://www.tepav.org.tr/upload/files/14256534230.Yabanci Savascilar_ve_Homegrown_Teroristler.pdf

Erol, Mehmet S. ve Kadir E. Çelik. “ABD’nin Suriye Politikasında Vekil Aktör Olarak Terör Örgütleri: YPG Örneği.” ANKASAM Bölgesel Araştırmalar Dergisi 2, Sayı: 2, (2018): 14-45.

Euronews. "Introduction: SYRIA." Erişim 3 Aralık 2019, (2018), https:// tr.euronews.com/2018/01/24/hollanda-d-sisleri-bakan-halbe-zijlstraypg-masum-degil

Europol. “EU Drug Markets Report.” Erişim 6 Aralık 2019, (2019), 35 36, http://www.emcdda.europa.eu/system/files/publications/12078 /20192630_TD0319332ENN_PDF.pdf

Holland-McCowan, John. "The Kurds After the 'Caliphate': How the Decline of ISIS has Impacted the Kurds of Iraq and Syria." ICSR, King's College, (London, 2018): 17-23. 
Suriye'de PKK Faaliyetlerinin Tarihî Arka Planı ve PYD Terör Örgütünün Siyasallaşma Çabaları

Hürriyet. “ABD’li komutanın general dediği PKK'lı!” Erişim 16 Eylül 2019, (2018), http://www.hurriyet.com.tr/gundem/abdli-komutaningeneral-dedigi-pkkli-40762427

Hürriyet. “Barzani: PKK ile PYD aynıdır.” Erişim 6 Aralık 2019, (2016), http://www.hurriyet.com.tr/gundem/barzani-pkk-ile-pyd-aynidir $-40074445$

International Crisis Group. "Flight of Icarus? The PYD’s Precarious Rise in Syria.” Middle East Report, Say1:151, (Belgium: 2014), 4-10.

İbrahim, Sarı. Kanlı Terör Örgütü PKK: PKK Katliamları ve İsim İsim Arananlar. Antalya: Net Medya Yayıncılık, 2017.

İçişleri Bakanlığı. "PKK/KCK Terör Örgütünün Suriye Kolu: PYD-YPG.” (2017), Erişim 7 Arallk 2019, https://www. icisleri.gov.tr/kurumlar/icisleri.gov.tr/IcSite/strateji/deneme/ YAYINLAR/\%C4\%B0\%C3\%87ER\%C4\%B0K/pyd_arapca.pdf

Kaşıkçı, Tamer. "Küresel Terörizm ve Birleşmiş Milletler Sistemi." The Turkish Yearbook of International Relations 47, (2016): 1-21.

Kekevi, Serkan ve Gökmen Kılıçoğlu. "Uluslararası Hukuk Açısından Çocuk Askerler ve PKK’nın Çocuk Askerleri/Militanları.” Ankara Barosu Dergisi, Sayı: 3, (2016): 489-495.

Kerman, İbrahim ve Ertan Efegil. “Terör Örgütü Pkk/Pyd'nin Suriye'de İzlediği İç Savaş Stratejisinin Değerlendirilmesi.” ANKASAM Uluslararası Kriz ve Siyaset Araştırmaları Dergisi, 1-2, (Ocak, 2017): 162-198.

Kışlalı, Ahmet Taner. Siyasal Sistemler Siyasal Uzlaşma ve Çatışma. Ankara: İmge Kitabevi, 2000.

Köylü, Murat. "Suriye, PYD-YPG Yapılanması ve Zeytin Dalı Harekâtı." Assam Uluslararası Hakemli Dergi, Sayı: 11, (2018): 70-86. 


\section{Mustafa ÇALIŞKAN}

Kulaksızoğlu, Beklan. "YPG PKK ile ne kadar bağlantılı?” 22 Ocak 2018, Erişim 13 Kasım 2019, https://www.dw.com/tr/ypg-pkk-ile-ne-kadar-ba \%C4\%9Flant\%C4\%B11\%C4\%B1/a-42261886

Kurt, Veysel. "Tunus, Misır, Libya ve Suriye Ordularin Arap Baharına Etkisi." Siyaset, Ekonomi ve Toplum Araştırmaları Vakfı (SETA) Analiz, Say1: 102, Temmuz, 2014, 7-21.

Maunsel, Françis Richard. "Central Kurdistan.” The Geographical Journal, (London: 1901), 121-144.

Milliyet. “ABD istedi YPG isim değiştirdi.” Erişim 18 Aralık 2019, 22 Temmuz 2017, http://www.milliyet.com.tr/dunya/abd-istedi-ypg-isim-

Üsküdar University Journal of Social Sciences, 2020; issue: 10 , 63-91 degistirdi-2488906

Montgomery, Hariet. Suriye Kürtleri. Çeviren: Ümit Aydoğmuş. İstanbul: Avesta Yayınları, 2017.

NTV. “ABD’li komutan PKK’lı üst düzey isimlerle görüntülendi.” Erişim 15 Kasim 2019, 26 Nisan 2017, https://www.ntv.com.tr/dunya/abdlikomutan-pkkli-ust-duzey-isimlerle-goruntulendi,GvW6zTMOoEyTjslvs $\mathrm{tMnDg}$

Özçelik, Burcu. "Explaining the Kurdish Democratic Union Party's Self-Governance Practices in Northern Syria, 2012-2018." Cambridge University Press, (Ekim 2019).

Özer, Verda. Hurriyetdailynews. "PYD 'promised' US to not give arms to PKK." Erişim 21 Kasım 2019, (2014), http://www.hurriyetdailynews. com/pyd-promised-us-to-not-give-arms-to-pkk-75307

Sarı, Buğra ve Murat Tinas. "Terrorism Threat Against Humanity and Democracy: The PKK Case.” Polis Akademisi Yayınları, Rapor No:17, Ankara, (Ağustos, 2018). 
Suriye'de PKK Faaliyetlerinin Tarihî Arka Planı ve PYD Terör Örgütünün Siyasallaşma Çabaları

Self, Andrew ve James Michael Ferris. "Dead Men Tell No Lies: Using Killed-in-Action (KIA) Data to Expose the PKK's Regional Shell Game." Defence Against Terrorism Review (DATR) 8, (2016): 9-35.

Sivrikaya, Halil Atilla. Arap Baharı'nın Suriye Sahasında Arap Diline Olan Yansımaları: PYD/YPG Örneği." Güvenlik Bilimleri Dergisi 8, Sayı: 2, (Ankara: 2019): 329-357.

Soner, Bayram A.. Ömer Aslan ve Hakan Kıyıcı. "PKK's Regional Franchise of Terror." Uluslararası Terörizm ve Güvenlik Araştırmaları Merkezi UTGAM, (Ankara, 2017): 1-43.

Şevkat, Uğur. "PKK kongresi: Amaç yeni ülke kurmak.” Erişim 13 Kasım 2019, 2002, http://arsiv.ntv.com.tr/news/146564.asp

Türkiye Cumhuriyeti Madrid Büyükelçiliği. PKK-PYD İlişkisi: PYD’nin Suriye'deki Etnik Terör Uygulamaları. Nisan 2017.

Yargitay 16. Ceza Dairesi. (2015). Karar No: 2015/3513 E. 2015/1456, 21.05.2015.

Üsküdar Üniversitesi Sosyal Bilimler Dergisi, 2020; sayı: 10 , 63-91 
